\title{
"Eu tô vivo e isso aqui é minha vida agora": produção de territórios e condições de existência no cotidiano de uma prisão
}

\section{Sara Vieira Antunes}

Universidade de São Paulo / São Paulo, SP, Brasil

A partir da experiência de duas pessoas aprisionadas em uma penitenciária feminina de São Paulo, o presente texto reflete sobre os modos de produção de territórios e condições de existência no cotidiano do cárcere. As formas criativas e táticas de adequar os ambientes de modo a torná-los morada e as redes de suporte, favores e afetos tecidas ao longo de anos são justapostas às formas de dominação e tentativas institucionais de anulação do sujeito aprisionado. Em situações extremas, o corpo torna-se território último de resistência, a partir do qual são agenciadas linhas de fuga capazes de produzir verdadeiras máquinas de guerra contra o Estado, de modo a fazer vida perseverar. Por meio de narrativas que fazem ver diferentes formas de produzir territórios de vidas vivíveis, busca-se discutir as fronteiras entre subjugação, resistência e criação no cotidiano de uma prisão.

"I'm alive, and this is my life now": territory production and existence conditions in a prison's daily life

ABSTRACT From the experience of two imprisoned people in a female penitentiary in São Paulo, this text reflects on the means of producing territories and existence conditions in their daily life. The creative and tactical ways of adapting the environments in order to make them home, so as the support networks, favors and affections woven overyears are juxtaposed with the forms of domination and institutional attempts to annul the imprisoned subject. In extreme situations, the body becomes the resistance's last territory, from which escape routes are put in movement for producing war machines against the State, in order to make life possible. Through narratives that allow us to see different ways of producing territories for liveable life, I seek to discuss the boundaries between subjugation, resistance and creation in daily life of a prison.

Prisão, território, táticas, resistência, cotidiano 
No mundão as pessoas pensam na gente que tá preso e acham que a gente não tem vida, que aqui é um tempo em branco que a gente passa. Mas aqui eu vivi grande parte da minha vida. Fui preso com dezoito anos, hoje tô com quase trinta. Aqui foi que eu amei pela primeira vez, casei três vezes, fiz meus amigos, aprendi quase tudo o que sei, quem eu sou. Pra sociedade a gente tá morto, tanto faz o que acontece. Mas eu tô vivo, e isso aqui é minha vida agora.

Pereira

Essa frase foi dita por Pereira', um sapatão/homem trans² preso há mais de dez anos no sistema penitenciário paulista. Pela boqueta ${ }^{3}$ de uma cela do castigo ${ }^{4}$ da Penitenciária Feminina de Santana (PFS) onde passou cerca de sessenta dias intermitentes confinado num espaço de oito metros quadrados, Pereira falava sobre a vida que construiu na cadeia. Vida marcada pelo confinamento em celas retangulares, pelo trânsito por determinados corredores e pelo regramento das horas vividas em pátios de concreto. Vida cercada por muros altos, arames farpados, grades de ferro e cabines de vigilância. Mas, nem por isso, vida em branco. Há mais de uma década preso, Pereira não avalia que os anos de sua juventude foram perdidos ou retardados pela ânsia interminável de algo que só poderia ser retomado lá fora. O que dizia pela boqueta da cela do castigo é que ali a vida também acontece. Ou, ainda, que ela precisa acontecer para que os anos de cadeia sejam possíveis.

A rota inicial da pesquisa de mestrado que desenvolvi na PFS foi substancialmente alterada pelos efeitos disparadores dessa frase. Inicialmente alinhada a uma certa abordagem temática da prisão, que privilegiava as dinâmicas do crime, a pesquisa sofreu paulatinamente a tração desse conjunto de palavras, levando a formulação de outros questionamentos, adjacentes a elas: como, então, seria possível produzir vida na prisão? Como fazer perseverar aquilo que é continuamente relegado ao mínimo necessário para não morrer? Como fazer o que é projetado para ser tempo em branco, uma vida passível de ser vivida?

Esses questionamentos só se tornaram possíveis quando abandonei as perguntas que me levaram a pesquisar o sistema prisional, em primeiro lugar. Iniciei o trabalho de campo em 2014, impulsionada pelo boom acadêmico dos anos $2000^{5}$ sobre a atuação e organização do Primeiro Comando da Capital (PCC). Queria saber das dinâmicas particulares à facção em um presídio feminino considerado dominado ${ }^{6}$. Interessava-me identificar os cargos ocupados - faxina disciplina, setor - , referentes à organização do Partido $^{7}$, a relação da população com outros presídios dominados, a dinâmica entre as pessoas aprisionadas, sua relação com o quadro de funcionárias(os) e problemas afins. Depois de meses cavando respostas às minhas próprias formulações, fui vencida pelo cansaço. O PCC era um problema meu e não delas.

\section{1| Todos os nomes próprios citados ao longo do texto são fictícios \\ 2 | Sapatão é um termo êmico para pessoas que corporificam atributos socialmente vinculados ao masculino nas penitenciárias femininas de São Paulo (PADOVANI, 2015). Ainda que o artigo assuma a presença de homens trans, utilizarei o universal feminino como padrão para fazer referência à população prisional.}

3| Pequena abertura na porta da cela

4 | Celas destinadas ao isolamento de pessoas que cometeram, segundo a direção da unidade, alguma falta disciplinar. O isolamento nessa unidade, varia de dez a trinta dias, sem permissão para o banho de sol.

5 | O inicio dos anos 2000 foi marcado pela explosão de pesquisas academicas que debruçaram-se sobre o fenomeno emergente do PCC: Adorno e Salla (2007), Telles e Hirata (2007), Biondi (2009), Marques (2009), Feltran (2008), Dias (2011), Mallart (2011), Codói (2010), Malvasi (2012) e Lima (2013) foram importantes referencias nessa direção.

6| Faz referência às instituições de privação de liberdade cuja população se orienta pelos preceitos e valores do Primeiro Comando da Capital. Sobre esse fenômeno, ver Mallart (2011).

7| Partido, Movimento, Quinze e Comando são sinônimos êmicos para PCC. 
Seus interesses e preocupações falavam sobre outras coisas. Queriam falar sobre o dia-a-dia da cadeia, os perrecos ${ }^{8}$ que circulavam, as dificuldades que encontravam nas atividades diárias, os casos e desafetos com outras companheiras, a família que deixaram "lá fora" e a família que fizeram "ali dentro". Queriam falar da vida na cadeia. Vida de forma ampla, e não vida do crime.

Esse "efeito de deslumbramento" derivado da frase de Pereira não foi imediato, mas aconteceu em retrospecto, depois de diversas visitas aos cadernos de campo em busca por conexões e análises preliminares. Strathern (2014) alerta que o trabalho de campo deve ser encarado como um exercício antecipatório, uma vez que não é possível saber de antemão o que posteriormente poderá ser significativo à pesquisa. Segundo a autora, as relações vividas e observadas em campo "devem ser valorizadas em si mesmas; qualquer informação resultante é um produto residual e muitas vezes inicialmente desconhecido" (:354). Essa imersão e abertura ao campo permite, em momento posterior de escrita e sistematização dos dados, que certos elementos apareçam como "revelações", produzindo um efeito de surpresa. Foi desta forma que, em meio às anotações sobre as irmãs que passaram pelo castigo e as opiniões diversas de apoio ou repúdio ao Partido, a frase de Pereira emergiu como potente articulador de uma série de problemas que pululavam do campo e extrapolavam a temática do PCC. Habitar uma prisão dominada certamente envolvia estar imerso em códigos e dinâmicas do crime, em formas de vida informadas pelo Comando. Contudo, o que Pereira e tantas outras interlocutoras me mostraram é que o PCC era apenas um vetor entre outros que costuravam os modos de fazer a vida na prisão.

Contra a ideia de tempo em branco, Pereira propunha que aquele havia sido tempo vivido: tempo no qual ele amou, casou, fez amigos, descobriu quem era e conseguiu construir, a despeito de inúmeras constrições, uma vida. Essa vida, portanto, não esteve sujeita — ou assujeitada — às contínuas tentativas de "mortificação do eu", como diria Goffman sobre a vida numa instituição total, tal qual a prisão. Para Coffman (1961), a totalidade do controle institucional é tamanha que as pessoas submetidas a ele tornam-se, gradativamente, despersonalizadas e mortificadas. Sua capacidade de agência estaria restrita a pequenos ajustamentos face uma instituição rígida, estável e fechada em si mesma. No entanto, Pereira e outras interlocutoras mostravam que o uso tático e criativo de algumas ferramentas tornava não apenas possível resistir à "mortificação do eu", como produziam novas territorialidades na prisão, esta também uma estrutura porosa e em constante transformação9.

O conceito de territorialidade desenvolvido por Perlongher (2008), em etnografia sobre a prostituição viril em São Paulo, trouxe importantes contribuições para pensar os modos de produção da vida na prisão. Inspirado nas reflexões de Deleuze e Guattari (1997), Perlongher pensa a ideia de territorialidade como uma formação subjetiva processual e fragmentada, portanto, não restrita a um espaço específico, nem fixada por certas relações ou estável no tempo. A ideia de
8| Intrigas, fofocas

9|Contra a ideia de uma instituição fechada em si mesma, Cunha (2003) chama atenção ao transbordamento da prisão para fora dos seus muros, uma vez que a experiencia prisional é também vivenciada pela população dos bairros periféricos que, por meio de processos de intensa criminalização e repressão policial, acabam se tornando clientes preferenciais" do sistema prisional. Nessa direção, Godói (2015) sugere que os fluxos de pessoas, coisas e ideias que conectam o "dentro" e o "fora" da prisão — chamados pelo autor de "vasos comunicantes" longe de serem marginais ao funcionamento da instituição, constituem-se como elementos indispensáveis à sua manutenção. $A$ perspectiva adotada pelos autores encara a prisão como uma instituição maleável e porosa, isto é, cujos limites extrapolam os seus muros e cujo funcionamento ordiánrio se mantem através dos fluxos entre o "dentro" e o "fora". 
territorialidade coloca em evidência a segmentaridade inerente ao sujeito, fragmentado por relações e pelos espaços em que circula. Ou seja, não existiria uma identidade estável de um sujeito fechado em si mesmo, mas constantes movimentos de territorialização, que consistem na apropriação de espaços subjetivos onde o sujeito se sente "em casa".

Como explica Zourabichvili (2004: 23), em Vocabulário de Deleuze, o território é aquilo que "circunscreve, para cada um, o campo do familiar e do vinculante, que marca as distâncias em relação a outrem, e protege do caos". Com isso, o autor explica que o território é a região de permanência da qual o sujeito se apropria e, com isso, produz identificação. No entanto, Deleuze e Guatarri (1997) destacam a instabilidade dessa apropriação, sempre sujeita a fuga, ao abandono ou a expulsão, criando espaços para a produção de novos territórios (reterritorialização). Assim, territorialização, desterritorialização e reterritorialização são movimentos que se alternam continuamente, formando o que os autores chamam de ritornelo, um agenciamento territorial constituído por esses três aspectos.

Nessa direção, sugiro que os esforços institucionais de anulação da existência dos sujeitos aprisionados, da produção de processos de "mortificação do eu" — os quais poderíamos chamar de desterritorializações forçadas e persistentes -, são disputados por movimentos de reterritorialização, de reapropriação de domínios familiares e vinculantes. Para se reterritorializar nesse contexto, são necessários não apenas ajustes em relação às estruturas de dominação (físicas e subjetivas), supostamente estáveis, mas uma série de artimanhas, bricolagens e tecnologias capazes de produzir linhas de fuga, pontos de desterritorialização que permitam a reterritorialização em outros domínios, onde é possível produzir um "em casa".

O conceito de tática apresentado por Michel de Certeau (2014) em A Invenção do Cotidiano pareceu-me, de outro modo, contribuir para a reflexão sobre as formas de produzir vida no cotidiano de uma prisão. O autor propõe o par estratégia/tática para pensar as práticas de consumo na articulação entre produção em massa e consumo privado, recusando uma visão determinista dos modos de consumo. Nesse esquema, estratégia é apresentada como um cálculo (ou manipulação) das relações de força a partir de um lugar próprio, privilegiado e distanciado do "campo de batalha", isto é, desde uma "base de onde se pode gerir as relações com uma exterioridade de alvos ou ameaças". A tática, por outro lado, uma vez privada de um lugar próprio, é forçada a improvisar dentro de condições limitadas num terreno que lhe é imposto, em estado de exposição total. Não tendo como se manter à distância, em local seguro para previsão e planejamento, a tática se configura como

movimento "dentro do campo de visão do inimigo", como diria Bullow, e no espaço por ele controlado. (...) O que ela ganha não se conserva"(...). Tem que utilizar, vigilante, as falhas que as conjunturas particulares vão abrindo na vigilância do poder proprietário. Aí vai caçar. 
Cria ali surpresas. Consegue estar onde ninguém espera. É astúcia. (...) Em suma, a tática é a arte do fraco (DE CERTEAU, 2014: 95).

A relação agonística entre tática e estratégia, proposta pelo autor, foi criticada por Kasper (2006) em sua etnografia sobre as práticas de moradores de rua na cidade de São Paulo. Segundo Kasper, o par tática-estratégia é apresentado por De Certeau numa perspectiva estritamente reativa, uma vez que a primeira aparece como uma ação sem projeto, pura contra-dependência, assentada numa dinâmica restrita aos pólos de ataque e contra-ataque. Apesar disso, Kasper postula que a característica agonística dessa relação é justamente o que a torna produtiva para pensar os modos de existência daqueles que habitam a rua, "seres desprovidos de um 'próprio', cuja vida se desenrola por inteiro dentro do campo de visão do inimigo" (idem: 22). Na esteira desse pensamento, julgo pertinente abordar o cotidiano prisional pela ótica da guerra. As pessoas encarceradas, uma vez privadas de um lugar próprio, submetidas à vigilância e ao regramento das suas atividades diárias, estão efetivamente em um campo de batalha pela manutenção das suas vidas. É plausível, portanto, falar em termos agonísticos, pois é disso que se trata. Manter-se vivo, negar-se a ter anos de suas vidas, até mesmo décadas, sujeitas a serem "passadas em branco", é efetivamente resistir às estratégias judiciais-penitenciárias de anulação e de extermínio. Disputadas num campo de desterritorialização permanente, onde as pessoas aprisionadas estão sujeitas a constantes deslocamentos e desapropriação, essas táticas produzem movimentos de reterritorialização que persistem em produzir territórios habitáveis, vidas possíveis.

É por esse conjunto de questionamentos e conceitos que busco discutir, neste artigo, as táticas de vida mobilizadas para se habitar a prisão. As experiências de Pereira e de Vanda, trazidas a seguir, não apenas dispararam uma série de questões à pesquisa, como continuaram a guiar o todo o processo de escrita, assumindo o primeiro plano. Os fragmentos compartilhados sobre o cotidiano de suas vidas, o que escolheram mostrar e contar de suas trajetórias entre grades, forneceram pistas para pensar as fronteiras entre subjugação, resistência e criação. Pensar essas fronteiras significou, sobretudo, refutar lentes analíticas que reduzem os sujeito aprisionados a receptáculos passivos de um poder que os destitui, que os mortifica e os incapacita. Aqui se buscou, portanto, levar a sério a frase de Pereira quando disse que a prisão não representou um tempo em branco em sua vida, mas foi um tempo vivido, tempo em que ele foi agente na construção de um território tornado, por ele, habitável.

Minha entrada na Penitenciária Feminina de Santana (PFS), localizada na cidade de São Paulo, foi possibilitada pela Pastoral Carcerária (PCr), entidade da Igreja Católica 
que presta assistência religiosa e jurídica a pessoas presas por todo o país. Em 2014, entrei no projeto "Letras que Libertam", coordenado por Vera, professora universitária do curso de Letras e voluntária da PCr. Juntas, realizamos visitas semanais no chamado pavilhão do Regime de Observação (R.O) da PFS, durante dois anos. O pavilhão segue o mesmo formato dos outros três da unidade: as celas são distribuídas por três andares em formato de $U$, de modo que é possível ter uma visão panorâmica das celas desde a entrada do pavilhão. No térreo, são alocadas as pessoas em tratamento clínico ou psiquiátrico; no primeiro andar, de um lado, ficam as pessoas que estão temporariamente na unidade (nas chamadas celas do trânsito) e, do outro, as pessoas que cumprem falta disciplinar nas celas do castigo (também conhecidas como pote). Por último, no segundo andar, ficam as pessoas que cumprem pena permanentemente isoladas do resto da população carcerária, nas chamadas celas do seguro ${ }^{10}$.

O ritmo do pavilhão do R.O, mesmo com os gritos entrecortados entre castigo e trânsito, era qualificado pela suas moradoras como calmo, tendo como referência os outros pavilhões da unidade. Foi por essa calmaria que Vanda, sem diagnóstico físico ou psiquiátrico para permanecer no R.O (tendo em vista ser local formalmente destinado para tratamento e recuperação), pediu sua transferência para lá depois de cinco anos vividos no pavilhão II da PFS. Aproximava-se do fim da sua sentença e dizia não suportar mais a convivência abarrotada e frenética dos outros pavilhões; queria a tranquilidade do menor número de pessoas que normalmente ocupavam o R.O.

Presa há oito anos, dizia que se tornou setor quando foi morar no R.O. Qualquer conflito ou intercorrência era reportado a ela que, com aparência frequentemente cansada, ficava grande parte dos nossos encontros, às sextas-feiras, resolvendo questões entre as presas e atendendo a demandas variadas. $O$ cargo de setor do paviIhão, legitimado pela organização do PCC, tornava-a responsável por entregar a boia ${ }^{11}$ nas celas, manter os corredores limpos e organizados, bem como fazer a interlocução entre moradoras e funcionárias.

Nos dias em que não havia muita demanda, Vanda sentava comigo e com Vera numa das celas que fora disponibilizada para realizarmos o projeto de leitura. Certa vez, começou a se queixar da sua memória, dizia não se lembrar mais das coisas, queria procurar um médico para saber se tinha algum problema: Já não lembro mais o que é comida do castigo e o que é do trânsito, vivo esquecendo tudo, já perdi a noção do tempoe das coisas aqui dentro. Preciso cuidar da minha cabeça. Diante da angústia de Vanda, Vera sugeriu que ela começasse a escrever aos poucos a história de sua vida — dizia que, assim como um músculo, a memória precisava ser exercitada frequentemente para se fortalecer; com o tempo ganharia força e vigor novamente. Entusiasmada com a sugestão, aceitou prontamente e pediu que Vera escrevesse essa história. Além da dificuldade que Vanda dizia ter na escrita, o conhecimento sobre a profissão de Vera como professora universitária de Letras fazia com que muitas a procurassem com dúvidas e requerimentos em relação a sua função como "professora de português", $\mathbf{1 0} \mid$ Nessas celas ficam as pessoas que pedem proteção em relaçãoao resto da população carcerária, permanecendo apartadas durante sua permanência na unidade ou enquanto houver indícios de risco quanto ao seu convívio com as demais.

11 Marmitex fornecido pela instituição, entregue individualmente nas celas 
bem como seu auxílio na escrita de cartas. Assim, combinamos que Vera escreveria a carta e eu iria participar como ouvinte interessada, tendo sua permissão para colocar a história "no livro que escreveria sobre a vida na prisão". Vanda dizia: Esse vai ser 0 meu testemunho de vida para as pessoas lá de fora. Fosse por meio do "livro que eu escreveria", fosse pela Pastoral Carcerária, queria que nós levássemos sua história "para o mundo", como testemunho de vida.

Na semana subsequente, como combinado, sentamos Vera, eu e Vanda no seu barraco, onde teríamos mais privacidade. Vanda, então, começou:

Eu perdi todo mundo no dia da chacina né, toda a minha família, quase todo mundo morreu. Meu pai era traficante, fazia as coisas tudo lá em casa. A gente morava numa chácara, daí onde uns caras vieram cobrar, acertar umas dívidas. Mas daí eles já chegaram atirando, a primeira que eu vi cair foi minha mãe, três tiros nas costas. Minha filha saiu correndo, daí o cara já foi atrás, deu tiro na cabeça. Matou dois irmãos meus e meu pai, mas esses eu não vi. Eu saí correndo para proteger meu filho, levei dois tiros nas costas, cai em cima dele, daí não lembro de mais nada... essa história ficou conhecida, passou no jornal e tudo, muita gente morreu na mesma casa, né. Até eu cair lembro de tudo, como se fosse um filme na minha cabeça. Só que daí eu fiquei em coma, muito tempo, nem sei mais quanto foi. Quando acordei é que me contaram tudo, que só eu consegui sobreviver naquele dia. O pior de tudoé que eu nem sei onde eles foram enterrados, até hoje não sei onde meus filhos foram enterrados.

Vanda começa a chorar, eu e Vera tentamos consolá-la, paramos por um tempo. Nesse intervalo, ela é chamada por uma agente carcerária para tomar seus remédios psiquiátricos. Eram vários. Tomado os remédios e, já mais calma, continuou a contar:

Então, depois que saí do hospital eu fiquei desnorteada né, não tinha para onde ir, daí eu fui para a rua. Eu tinha só dois irmãos vivos que não estavam no dia da chacina, mas um estava preso e o outro na rua, era alcoólatra. Daí eu fui para a rua também né, comecei a usar muita droga (crack), dormia na rua, em qualquer lugar, não tinha higiene, cuidado, nada. Era para eu ter ficado doente, pegado alguma coisa, do jeito que eu vivia. Fiquei uns dois anos na rua assim, vendendo droga para consumir, vivia para a droga... até uma hora que eu rodei, né. Peguei dez anos. Esses dias foi que eu percebi que já estou aqui há oito. É tempo demais nesse lugar, acho que por isso que não lembro mais das coisas, a gente fica ruim da cabeça. É difícil viu, de vez em quando me dá um pânico sabe, não sei o que vai ser da minha vida quando eu sair. Não tem ninguém me esperando lá fora. Meus irmãos nunca vieram me visitar, já mandei carta, eles não respondem, já desisti. Tenho só uma carta do meu irmão, de seis anos atrás. (...) É assim fia, na cadeia é você e Deus, só ele não te abandona. Meu irmão, quando estava preso, eu ia visitar ele todo mês, mesmo quando estava grávida de sete, oito meses. Mas desde que vim para cá, nem jumbo, nem carta, nada. É assim mesmo, isso é cadeia.

Sem o auxílio valoroso dos jumbos ${ }^{12}$, Vanda buscava manter algum trabalho formal pela penitenciária, de forma a adquirir pecúlio ${ }^{13}$ suficiente para cobrir os gastos

12 | Sacolas com alimentos, produtos de higiene, limpeza, roupas, cigarros (entre outras coisas) levados pelas visitas às pessoas em cumprimento de pena

13 | O pecúlio "funciona como um sistema bancário no interior do sistema prisional, através do qual cada preso é dotado de uma espécie de conta em que depositarão ou os salários daqueles que trabalham, ou os recursos disponibilizados pelos familiares" (...). "O setor administrativo faz circular uma lista de mercadorias permitida entre os presos", (Codói 2015: 75), mercadorias que não são permitidas entrar pelo jumbo. 
básicos com produtos de higiene, roupas e alguns alimentos. Quando, por ventura, não estava empregada, realizava serviços informais para a própria população ${ }^{14}$, cujo pagamento é feito com maços de cigarro — o dinheiro da cadeia, como dizia: lavava

$\mathbf{1 1 4} \mid$ Diz respeito a toda a população carcerária, exceto as pessoas presas no seguro. roupas para outras pessoas, confeccionava e vendia materiais de crochê para uso e decoração dos barracos e realizava corres com celular e/ou drogas, ainda que tentasse evitá-los a fim de não cair no castigo.

Desde que foi para o R.O, considera que sua vida na cadeia melhorou. Passou a trabalhar como setor, estava mais distante da bagunça, da muvuca e da falação de crime 0 dia todo no pavilhão. Apesar de bastante atarefada com suas funções, dizia não ser nada parecido com a convivência de quase quinhentas pessoas morando em cada lado dos outros três pavilhões. Desde que chegou no R.O, pôde permanecer na mesma cela, compartilhando-a ocasionalmente com diferentes pessoas ao longo dos anos.

$\mathrm{Na}$ entrada do seu barraco, um pano florido servia como cortina para a porta. Segundo Vanda, o pano serve para manter a privacidade dentro do barraco quando as celas ficam abertas, mas também quando se fecham, uma vez que a abertura da boqueta permite a visão parcial do interior da cela, para quem passa pelo corredor. Deste modo, mesmo quando as portas são fechadas, é o pano que sela a disjunção entre os corredores vigilantes e o espaço doméstico e privado daqueles poucos metros quadrados. Na parte de fora da boqueta, Vanda deixava uma toalha de crochê com bolsos costurados para fora, de forma a acomodar os pães que eram entregues no café da manhã. Assim como nas outras celas do pavilhão do R.O, a privada e a pia ficavam no canto do lado esquerdo, logo em frente à cama. Com cerca de $8 \mathrm{~m}^{2}$, a maior parte das coisas se empilhava verticalmente. O chão era fundamentalmente ocupado por duas camas estreitas de concreto sob um colchão fino de solteiro; entre elas, um tapete de crochê feito à mão, material correntemente confeccionado e comercializado dentro da prisão. Além do tapete, havia uma espécie de prateleira feita do mesmo material, onde Vanda colocava roupas dobradas e alguns produtos de higiene.

Na parede defronte à entrada, via-se uma janela retangular e comprida formada por grades geladas de ferro, estreitamente justapostas. Daquele lado do pavilhão, as janelas avistavam uma imensa parede de concreto, marcada por rachaduras e pequenas fissuras aparentemente causadas pelo tempo e pelas intempéries. Janelas que, no barraco de Vanda, eram cobertas por um lençol branco com flores bordadas, preso nas suas extremidades à parede e acobertando a visão cinza de suas grades. Em frente à cama da pessoa que, nesse período, dividia o barraco com Vanda, uma pequena televisão permanecia ligada, com o som baixo que compunha o plano de fundo de vozes entrecortadas pelos corredores e andares do pavilhão. Juntamente a compor a sonoridade do ambiente, ficava um rádio ligado durante todo o período dos nossos encontros. $\mathrm{O}$ som, muitas vezes acompanhado pela cantoria das moradoras, variava com notável tranquilidade desde músicas gospel ao sertanejo e o funk. Misturado a isso, tantas vezes ouvíamos os gritos que vinham do primeiro andar, a gritar senhora!!! 
(expressão utilizada para se dirigir às agentes carcerárias), a pedir favores para as setores do pavilhão, ou a conversar animadamente entre as boquetas - fatores que, nas primeiras vezes que entrei na prisão, demandavam esforço redobrado de minha parte na atenção das escutas individuais.

Gritos, conversas paralelas, o barulho metálico de grades e chaves, o som do rádio e televisão ligados compunham a sonoridade do R.O que, ora estridente, ora amena, segundo Vanda não se comparava à multidão de sons simultâneos entre as cerca de quinhentas pessoas em cada bloco dos outros três pavilhões. Há oito anos presa na mesma penitenciária, Vanda parecia conhecer minuciosamente os ambientes e os diferentes ritmos dos pavilhões em que habitou. Enquanto conversávamos, parecia distinguir claro e rapidamente os gritos que a ela se dirigiam, aqueles que indicavam confusão por vir e a falação corriqueira entre as celas. Por vezes nossa conversa fora abruptamente interrompida pela sua saída ao corredor para averiguar a razão da vozearia; de minha parte, não conseguia notar qualquer diferença entre os gritos habituais e aqueles que a mobilizavam a agir.

A pesquisa de Allen Feldman (1991) com presos políticos na Irlanda do Norte é primorosa para pensar sobre os efeitos da ambientação sonora na vida da prisão. $A$ partir dos relatos feitos pelos presos que participaram do chamado "Dirty Protest", Feldman reflete sobre as distintas habilidades desenvolvidas para resistir às violências sofridas no sistema prisional| ${ }^{15}$. De forma a driblar a escuta e compreensão dos guardas, os presos políticos passaram a se comunicar por gritos e por escritos em gaélico, feitos com suas próprias fezes, em cortinas de lençol. Além do uso do gaélico, língua dificilmente compreendida pelos guardas, o fracionamento dos sons produzidos na vivência adensada do cárcere, tornou-se aprendizagem necessária e ferramenta política para suas ações. O som, capaz de extrapolar as limitações do isolamento celular, fazia da voz e dos ouvidos "órgãos autônomos de prática política". Em outras palavras, a escuta atenta aos movimentos sonoros mais sutis - e mesmo aos momentos de silêncio - tornou-se tática para superar as barreiras visuais que os impossibilitava de acompanhar o que transcorria no pavilhão. Fechados nas suas celas, os presos desenvolviam "o ouvido autônomo e a voz descorporificada, que estava 'no ar', livre e transcendente" (idem: 210, tradução minha).

$\mathrm{O}$ argumento de Feldman indica que a familiarização da variedade de movimentos do campo sonoro podem fazer da voz descorporificada uma potência política da sociabilidade prisional. A partir dessa compreensão, pode-se dizer que o "plano de fundo barulhento" que inicialmente desfocava minha atenção, parecia fracionado por Vanda pela qualificação sensível e aprimorada dos sons que poderiam representar conflitos, demandas direcionadas a ela ou simples conversas cotidianas. A atenção continuada à variação sonora do pavilhão parecia decorrer da familiarização do ambiente pela vivência prolongada, mas, também, como sugere Feldman, como tática para superar as barreiras visuais e permanecer vigilante, atenta ao ritmo e aos
15 | O "Dirty Protest" foi uma greve desencadeada por prisioneiros políticos de uma penitenciária masculina na Irlanda do Norte, que protestavam contra o uso de uniformes equivalentes àqueles usados por pessoas condenadas por"crimes comuns". A resistência desse grupo às diversas violações perpetradas pelos agentes carcerários progressivamente escalou, levando a um tamanho ciclo de violência que em determinado momento, 0 grupo passou a tomar medidas extremas. Entre elas, usavam suas fezes para escrever recados e também para criar uma ambiente de repugnância que, eventualmente, obrigou os guardas a cessarem as agressões. Falarei mais sobre a grave adiante. 
fluxos dos ambientes pelos quais tornara-se responsável. Como setor, cabia-lhe intermediar e estar a par dos conflitos e trânsitos que transcorriam no pavilhão. O "ouvido autônomo e a voz descorporificada", como coloca Feldman, é o que parecia conectar Vanda com as celas do trânsito, castigo e seguro, desde os momentos de silêncios até a diversidade de sons, gritos e exclamações pelos três andares do pavilhão.

No entanto, ao passo que a memória sensorial de Vanda parecia atinada às mais sutis vibrações de sons e movimentos, sua memória prática dos afazeres cotidianos e da passagem do tempo parecia esmorecer significantemente. Em sua fala, dizia ter começado a perder a noção do tempo, a esquecer-se das coisas e das memórias fugidias. Sobre sua vida, sabe narrar o que considera o momento mais traumatizante de sua história, que faz deste um testemunho de vida. Tal testemunho, suscitado por Vera como "exercício da memória", é trazido ao presente nas palavras de Vanda em forma de eventos conectados pela experiência do trauma, como uma maneira de dar inteligibilidade à sequência de fatores que a conduziram à situação do cárcere.

A antropóloga indiana Veena Das (2007), em etnografia com mulheres que vivenciaram imensa violência em função dos processos de repartição da Índia, discorre sobre as formas sutis e silenciosas de revisitar eventos traumáticos por meio da atualização cotidiana de (re)fazer a si mesma no exercício diário e persistente de retomar a vida. A ideia trazida pela autora é que esses eventos traumáticos não ficam depositados em um passado longínquo e esquecido, sobre o qual fala-se com distanciamento; pelo contrário, tais eventos envolvem o presente como uma atmosfera que precisa ser superada na prática diária de seguir a vida. Por meio dessa abordagem, Das busca esmorecer as recorrentes oposições entre vítima e agressor, agência e opressão, que partem da perspectiva do excepcional, do extra-ordinário em relação à experiência da violência e às formas de superar seus efeitos. Ao trazer a análise para o plano do ordinário, do cotidiano, ações singelas como o preparo do alimento, os afazeres diários, a organização dos ambientes e o cuidado com o cultivo das relações emergem como formas de comunicar silenciosamente a dor e, nesse exercício, buscar transpô-la. De acordo com a autora, estas são formas de agência que não aparecem como atos heróicos e fantásticos de resistência, mas exercem-se nas sutilezas diárias de tornar o cotidiano habitável.

As indicações de Das sobre as diferentes formas de manifestar e lidar com os efeitos de eventos traumáticos foram essenciais para entender os esforços de Vanda em produzir um testemunho de vida e, sobretudo, olhar para a extensão desses esforços nas práticas menores do seu cotidiano. Diante da perda de grande parte dos vínculos familiares, da falta de suporte material e afetivo dos irmãos ainda vivos, Vanda conseguiu, ao longo dos anos, articular uma extensa rede de trocas, favores e escambos de habilidades que equiparam seu barraco de memórias, histórias e sentidos afetivos. O quarto sempre impecável, o chão "limpo até mesmo com as mãos", como já me disse ter feito tantas vezes na falta de utensílios; todo o trabalho de decoração 
com enfeites, materiais feitos de crochê, cortinas, adornos e cores compunham um ambiente acolhedor e íntimo que, a despeito de todas as constrições e formas de violência próprias à prisão, era feito casa.

Ao tentar converter a dor do evento traumático que envolve a chacina da sua família em testemunho de vida, Vanda parecia criar discursivamente um elo temporal com o passado que a reconduzia ao momento presente e às formas como cuidava diariamente de seus efeitos. A leitura que faço da etnografia de Das é que esses eventos traumáticos não são revisitados apenas em suas expressões discursivas, mas se fazem presentes nas formas pelas quais as pessoas conduzem suas vidas no cotidiano, em práticas ordinárias aparentemente banais. Nesse sentido, a experiência vivida por Vanda no passado não se atualizava somente quando, sentada na cama do seu barraco, ela colocava em palavras a sequência de acontecimentos que a conduziram ao presente; seu trauma, supostamente alocado num passado longínquo de uma memória enfraquecida, era atualizado cotidianamente nas formas pelas quais ela conduzia sua vida: na lida com as relações diárias, nas tarefas e afazeres práticos, na maneira que organizava e cuidava do ambiente em que morava e mesmo nos silenciamentos da memória.

Nesse registro, pode-se dizer que o barraco de Vanda, suas práticas cotidianas, bem como seu testemunho, falavam sobre o evento traumático que vivera justamente porque informava sobre a necessidade de se reterritorializar, de criar domínios familiares e vinculantes, seja na formação de laços afetivos, na produção material de uma ambiência acolhedora ou na constituição de noções de permanência e segurança. Nos anos de cadeia esquecera números de telefone, endereço de onde sua família morava, qualquer referência rastreável do seu passado. Os anos de pena já chegavam ao fim e, além de não ter qualquer conhecimento sobre quando seu alvará de soltura finalmente chegaria, não tinha perspectiva alguma do que faria e para onde iria, uma vez em liberdade. Assim, o momento presente era o terreno palpável sobre o qual podia dar seguimento a uma existência que fora devastada, de modo a produzir uma narrativa sobre si mesma e tecer outros territórios existenciais.

Contrariando o paradigma da prisão incapacitante, no qual as pessoas encarceradas estariam submetidas a um controle total e mortificador, permanentemente reféns de movimentos de desterritorialização, Vanda foi capaz de (re)criar espaços físicos e subjetivos nos quais sua vida pôde perseverar. O acúmulo de conhecimentos sobre a prisão e seu funcionamento foi justamente o que a permitiu criar, de forma tática e bricolada, melhores condições para terminar os anos que restavam até o fim de sua pena.

Apropriar-se da mecânica da prisão e torcê-la ao seu próprio benefício foi, no caso de Vanda, um exercício silencioso e discreto, por meio do qual conseguiu direcionar determinados fluxos e produzir um território material e afetivo considerado por ela mais salutar. Em outro caso, o tensionamento da mecânica prisional a fim 
de desencadear determinado deslocamento só foi possível quando uma "máquina de guerra" foi colocada em marcha. De modo sistemático e violento, Pereira passou meses entranhado nas engrenagens do sistema carcerário forçando uma linha de fuga que o conduziria de volta ao território onde escolheu terminar o tempo de sua pena. Irresignado com a transferência indesejada para outra unidade, passou longos períodos vivendo um movimento de desterritorialização absoluta. Discuto, a seguir, a tática de meter o louco pra rodar o sistema.

\section{METER O LOUCO PRA RODAR O SISTEMA}

Pereira estava, pela terceira vez, cumprindo castigo no pavilhão do R.O. Durante sua última passagem, ficou muito amigo de Vanessa, uma das mulheres sob tratamento psiquiátrico que habitava o térreo do pavilhão. Ficavam horas a conversar: ele com a cabeça para fora da boqueta e ela, no corredor do andar de baixo, em pé com a cabeça inclinada para cima. Vanessa frequentemente se recusava a tomar banho, reclamava do sabor insosso da comida e, por vezes, passava o dia sem se alimentar. As condições precárias de seu barraco, ocupado apenas por um colchão de espuma sem lençol, um travesseiro e quase nenhum pertence pessoal, também sugeriam os limites da sua capacidade de cuidar de si. Pereira passou a aconselhá-la, pedindo para que arrumasse melhor seu barraco, tomasse banho e se esforçasse para se alimentar regularmente.

Certa vez, a lâmpada da cela de Vanessa queimou. Os dias passaram e nada foi feito pelas funcionárias do pavilhão. Quando o sol ia embora, Vanessa permanecia horas fechada na cela escura, até finalmente adormecer. Pereira, contrariado com a situação, começou a demandar das guardas que fizessem alguma coisa, que arrumassem as condições do barraco dela, que a levassem para tomar banho, que parassem de tratá-la com indiferença. Quase ao fim dos trinta dias no castigo, nada havia mudado em relação às condições de habitação na cela de Vanessa. Quando Pereira finalmente pisou para fora do pote, escoltado pelas guardas de volta ao seu pavilhão, não se conteve. Saiu da cela xingando-as e acusando-as de serem responsáveis pelas condições precárias com que Vanessa vivia. De volta ao castigo, dessa vez por desacato, aguardava o resultado da sindicância ${ }^{16}$ que diria quantos dia ainda permaneceria lá dentro. Contudo, devido ao seu histórico de faltas disciplinares, foi decidido que ele seria transferido para outra unidade, possivelmente uma das penitenciárias do fundão, onde as conhecidas condições de superlotação e precariedade indicavam um horizonte sombrio.

Depois de nove anos preso na Penitenciária Feminina de Santana, Pereira havia estabelecido um território marcado por laços afetivos e relativo conforto material. Recomeçar uma vida em outra penitenciária significaria refazer o caminho de anos na construção de uma região tornada por ele familiar, habitável. O 
pavilhão onde vivera todos esses anos havia se tornado um lugar seguro, onde era conhecido e respeitado e cujas dinâmicas ele sabia trafegar. A transferência abrupta para outra unidade nem ao menos o permitiu levar seus pertences pessoais ou comunicar seus parentes sobre o bonde ${ }^{17}$. Teria permissão para enviar cartas novamente ou receber visitas somente quando fosse liberado do pote de um presídio por ele desconhecido.

Os meses se passaram no projeto de leitura. Vanessa seguia perguntando quando Pereira iria retornar para visitá-la no R.O. No entanto, não tínhamos notícia do seu paradeiro, nem sabíamos dizer se ele acabaria por terminar sua pena nos presídios afastados do fundão. Certo dia, passando pelas celas dos castigo, encontrei uma amiga de Pereira que havia dividido o pote com ele em mais de uma ocasião. Trazia notícias. Segundo ela, Pereira não aceitaria ficar preso em qualquer outra unidade que não fosse a PFS. Ela me explicou, então, que para conseguir retornar, Pereira estava metendo o louco pra rodar o sistema. Relatou que ele havia passado os últimos cinco meses por praticamente todas as penitenciárias femininas do estado de São Paulo, de castigo em castigo. Em cada unidade que chegava, produzia tamanha balbúrdia e estrago que, como consequência, era expulso para o pote de outra penitenciária. Ao chegar, quebrava a estrutura das celas, colocava fogo nos colchões, brigava com as/os guardas, se cortava, ameaçava se matar, produzindo um tal transtorno que o/a diretor/a do presídio não tinha escolha senão transferi-lo para outra unidade do sistema. Nisso, o tempo de castigo alargava-se. Na agressividade das suas ações, a violência que para ele retornava era cada vez mais brutal.

Mais tarde, relembrando esses meses, Pereira contou sobre o tempo que passou de calabouço em calabouço, resistindo a todas as formas de violência, desde a absoluta privação - de alimentos, roupas, luz, circulação de ar - até espancamentos continuados por parte de agentes carcerários. Apesar de todas as atrocidades que viveu, assevera que o pior lugar pelo qual passou, onde por vezes acreditou que não conseguiria sair são, foi o "Manicômio Judiciário" de Franco da Rocha. Conta que, enquanto esteve lá, toda e qualquer manifestação sua de indignação ou tristeza era respondida com a administração de pesados psicotrópicos, por via oral ou mesmo injeções, aplicadas à força. Nesse período, diz, havia perdido a noção do tempo, já não sabia mensurar se estava lá há dias ou há semanas. Passava a maior parte do tempo dormindo e, quando acordado, encontrava dificuldade em realizar tarefas simples, como tomar banho e se alimentar, tamanha a letargia produzida pelos medicamentos. Quando aplicavam-Ihe injeções, conhecidas como "sossega-leão", sentia seu corpo rígido e embalado por espasmos que o faziam andar de forma mecânica, feito um robô que marcha.

Depois de algumas semanas no manicômio, conheceu uma mulher em situação semelhante à sua - encontrava-se internada sem qualquer justificativa psiquiátrica. Ela, então, o ensinou uma tática para escapar dos efeitos imediatos
17 | Expressão que designa a transferência de pessoas presas entre unidades do sistema prisional. 
dos psicotrópicos e também do risco de, a longo prazo, tornar-se quimicamente dependente deles. Os psicotrópicos administrados regularmente (salvo os injetáveis, aplicados em situações de "agitação") eram consumidos via oral, seguidos da inspeção da boca para verificar sua deglutição. Para escapar dos seus efeitos, indicou que andasse sempre com uma garrafa de desinfetante ao seu lado, suficientemente pequena para não chamar atenção, mas capaz de servir ao propósito. Explicou que, após engolir as pílulas e passar pela inspeção, deveria tomar um gole generoso de desinfetante de modo a provocar o vômito automático. Com isso, todo medicamento seria expulso, deixando apenas rastros dos efeitos de um produto tóxico em seu sistema... Numa economia dos sofrimentos, calculava ser este um mal menor.

Quando já dominava a tática de expelir os medicamentos, passou por uma consulta com o psiquiatra que visitava a unidade regularmente. Sem os efeitos mecânicos ou letárgicos dos psicofármacos, conseguiu convencê-lo da sua "normalidade", recebendo "alta" para poder sair do manicômio.

Os meses passavam e Pereira não vislumbrava o fim próximo do circuito por todas as unidades femininas do estado. Estava seguro de que o método eventualmente funcionaria: outras companheiras já haviam feito o trajeto completo. Algumas levavam meses, outras mais de um ano, mas finalmente retornavam ao ponto de partida. No seu caso, por volta do sexto mês rodando o sistema, desgastado e já sem energias, Pereira recuou da empreitada. Consentiu sair do castigo, permanecendo no pavilhão do Centro de Detenção Provisória (CDP) Feminino de Franco da Rocha. Nesta ocasião, me enviou uma carta falando do seu paradeiro, o que me permitiu visitá-lo através da equipe da Pastoral Carcerária de Franco da Rocha, a qual visitava a unidade regularmente.

Finalmente, consegui reencontrar o Pereira. (...) Assustei quando o vi. Estava magro, abatido, uma olheira funda e o cabelo, antes tão arrumado, agora estava todo desgrenhado. Parecia cansado, triste. Me falou que decidiu ficar em Franco da Rocha porque não aguentou o sofrimento de rodar o sistema. Cansou e se rendeu, decidiu ficar por lá mesmo, até porque descobriu que sua sentença estava perto do fim. Ainda assim, acha muito difícil passar esse tempo lá. Diz que é muita mulher falando na cabeça dele o dia todo, muita gente junto no mesmo espaço, não tem tempo sozinho... Privacidade? Nunca. Fala que lá é muito veneno, muita injustiça, não tem trabalho nem nada pra fazer. Me mostrou a cela onde fica. Bem diferente das duas camas por cela na PSF, lá ele compartilha o espaço com cerca de trinta mulheres, amontoadas entre o chão, beliches e umas redes improvisadas (trecho extraído do caderno de campo-12/09/2016).

Depois de três meses acompanhando Pereira em visitas quinzenais nos pátios do pavilhão II do CDP de Franco da Rocha, fui encontrá-lo novamente no castigo do 
mesmo CDP, dias antes do seu aniversário. Ele dizia rindo, com ironia, que ganhara alguns dias no pote de "presente de aniversário", mas também sorria pela notícia ainda incerta que me segredava em euforia: ouvira boatos de que seria transferido para a Penitenciária Feminina de Santana. Duas semanas depois, retornei ao CDP e já não o encontrei. Suas companheiras de cela confirmaram: ele estava de volta à PFS.

Após meses travando uma verdadeira guerra nos castigos de praticamente todas as penitenciárias femininas do estado de São Paulo e semanas imprecisas "marchando" ou completamente dopado no Hospital de Custódia e Tratamento Psiquiátrico (HCTP) de Franco da Rocha - acertadamente referido como "manicômio judiciário" —, Pereira finalmente conseguiu terminar de rodar o sistema.

Uma importante dimensão que constitui o funcionamento do cárcere é a de produzir a gestão das mobilidades e dos fluxos daqueles que aprisiona, projetando, com isso, movimentos de dispersão e de fixação. Mais do que confinar, a prisão opera numa lógica de circulação e concentração, de captura e movimento (MALLART, 2019). Do mesmo modo que restringe direitos e míngua as condições materiais mais elementares ao cotidiano, dá vazão aos fluxos advindos de redes familiares de apoio, aos trânsitos e comércios internos, ao realocamento de pessoas entre os diferentes pavilhões por critérios de convivência, aliança e rivalidade. É uma engrenagem que se expande apoiada pela mobilização e engajamento contínuos de agentes fora do quadro de funcionários do Estado: familiares, movimentos sociais e entidades voluntárias são imiscuídas ao desempenho ordinário e previsto da prisão (Godói, 2015).

Codói (2015) situa a prisão como um dispositivo de governo de populações que, de modo perverso, consegue fazer "do mínimo da existência, do imperativo e inegociável da vida, algo que depende do engajamento contínuo de atores vários, (...) e que converte os efeitos [desse engajamento] numa espécie de concessão benevolente sua" (idem: 220). Longe de ser uma instituição destinada ao fechamento e controle absoluto de tudo o que envolve aqueles que encarcera, ela se estrutura e se expande pela regulação diferencial de suas velocidades e intensidades. Não os imobiliza por completo, mas retém e dispersa; concentra e faz circular; dopa e coloca para marchar.

Metero louco pra rodar o sistema afronta diretamente esse mecanismo de gestão dos deslocamentos, uma vez que impõe forçosamente um vetor de desterritorialização e um destino último de reterritorialização. Adentra, portanto, um regime de guerra, cuja ambição nômade implica a mobilização de uma violência dirigida contra o aparelho do Estado, isto é, contra a conservação do seu poder de dispor sobre os fluxos e velocidades. Se "o Estado se define pela perpetuação ou conservação de órgãos de poder" (Deleuze e Guattari, 1997: 20), se sua preocupação central é conservar 
e concentrar, qualquer indisciplina que questiona sua hierarquia, que promove 0 abandono ou a fuga, que contraria sua forma arborescente, está dirigida contra o aparelho do Estado.

O processo de acumulação social de conhecimentos sobre a mecânica do cárcere levou Pereira a empreender uma linha de fuga dentro do aparelho de Estado, objetivando sua engrenagem para irromper uma determinada trajetória institucional. Para isso, um estado de desterritorialização contínua foi ativado por uma máquina de guerra que ameaçava dissolver-se numa linha de abolição, uma vez que sua sanidade, e até mesmo sua vida, permaneceu ameaçada pela débil fronteira entre atos de resistência e a ameaça de destruição.

Na pesquisa de Karina Biondi (2010) em penitenciárias masculinas, a expressão meter o louco também aparece na fala de seus interlocutores como uma certa atitude frente a situações adversas. Meter o louco consistiria basicamente em "tentar a sorte" (idem:123) ao acionar táticas improvisadas e arriscar situações com o intuito de alcançar o objetivo almejado. A autora recupera o relato de um de seus interlocutores sobre um plano de fuga que escapou ao fracasso devido a uma atitude inusitada de improviso. O plano envolvia a passagem do grupo pela enfermaria da unidade, no entanto, o integrante responsável por abrir a enfermaria não compareceu na hora marcada. Assim, o interlocutor de Karina solucionou a situação cortando abruptamente seus próprios lábios e encenando um desmaio, de modo a ser levado rapidamente à enfermaria e, com isso, poder dar continuidade ao plano de fuga. A autora sublinha que, embora essas atitudes repentinas pareçam aleatórias e impulsivas, são fruto de um longo processo de aprendizagem, de um trabalho laborioso e criativo de lidar com as adversidades da vida em um contexto de controle e confinamento:

\footnotetext{
o improviso envolve ao mesmo tempo o domínio do corpo, do discurso, as faculdades sensoriais e a capacidade de raciocínio. Corpo, mente e sentidos são, aqui, indissociáveis à construção de uma habilidade que é reativa, mas que também é aprendida, trabalhada, fruto de treinamento, criatividade, imitação, intuição e muita prática (idem: 126).
}

O conhecimento sobre o funcionamento da engrenagem prisional, junto ao domínio do seu próprio corpo foi o que conferiu a Pereira a confiança necessária para meter o louco e alcançar objetivo almejado: retornar à PFS. Numa economia dos sofrimentos, calculou que as angústias e violências às quais estaria submetido nesse trajeto eram inferiores a possibilidade de terminar os anos de sua pena em outra penitenciária. No meio do percurso, contudo, chegou a recuar do plano inicial, conformando-se a ideia de permanecer nas celas superlotadas do CDP de Franco da Rocha. O corpo cansado apresentava os efeitos cumulativos de uma trajetória massacrante. Magro, olheiras profundas, feição abatida, ressaltos e 
fissuras na pele falavam de caminhos tortuosos. As diversas celas do castigo pelas quais passou ao longo dos meses também guardavam a textura do confronto contra os aparelhos de Estado.

A etnografia realizada por Feldman (1991) junto aos prisioneiros da Irlanda do Norte, mencionada anteriormente, mostra a potencialidade do corpo como artefato político de luta e de resistência. No contexto do "Dirty Protest", a insurgência dos prisioneiros contra as violações perpetradas pelos agentes carcerários tinha como ferramenta última o uso dos seus próprios corpos. Desprovidos de outros materiais e de qualquer canal de comunicação com o espaço extramuros, transformaram seus corpos numa máquina de guerra escatológica contra as violências da prisão.

A greve teve início pela recusa de um grupo de presos políticos em usar os mesmos uniformes que os "presos comuns". A primeira manifestação do grupo foi seguida da intensificação da violência a eles aplicada durante as revistas dos seus uniformes. Em resposta a isso, os presos passaram a negar o uso de qualquer roupa, permanecendo nus e cobrindo-se apenas com os cobertores usados para dormir, fato que os tornou conhecidos como "The Blanketmen". A partir de então, as revistas corporais recrudesceram. Tornou-se recorrente a abordagem violenta dos agentes carcerários nos procedimentos de inspeção retal e nos supostos procedimentos para higiene dos presos durante os banhos. Segundo consta, os guardas "raspavam as cabeças e pelos do corpo dos prisioneiros, esfoliavam a pele com duras escovas que chegavam a arrancar a pele" (FELDMAN, 1991: 189). A resposta a essas violações tomou a forma de uma "greve de limpeza", na qual os presos recusavam-se a tomar banho. Com o tempo, passaram urinar e a defecar na própria cela, de modo a impedir a condução possivelmente violenta dos guardas aos banheiros coletivos. A criação do que Feldman chama de uma "ecologia escatológica" dos corpos e das celas foi responsável por criar uma máscara de abjeção que criava repugnância por parte dos guardas, desencorajando-os a dar continuidade às inspeções. Por meio de uma ambiência de abjeção, os presos fizeram das suas cavidades e da própria cela "recessos protetivos e abrigo que repeliam as penetrações ópticas do regime prisional" (idem: 199).

A recusa ao banho e a produção de um cotidiano imerso em excrementos corporais passou a incidir, inclusive, na morte de presos em decorrência das doenças proliferadas nesse contexto. Assim, seus corpos não estavam apenas submetidos à condições degradantes e infames, mas à iminência da morte. O corpo, recurso último de resistência, tornava-se instrumento e mimese subversiva do poder. Nessas situações em que a desterritorialização das formas de vida é tamanha, o corpo parece se tornar o território último a partir do qual é possível redirecionar e reverter circuito de força, produzindo linhas de fuga que podem, eventualmente, tornar-se linhas de abolição, criando regiões onde a vida já não é mais possível. 
As reflexões trazidas por Feldman ajudam a pensar sobre as práticas de metero louco. Tanto na etnografia de Biondi, quanto no relato de Pereira, metero louco aparece como uma desenvoltura capaz de criar soluções ousadas diante de situações extremas. De forma diferente das táticas acionadas por Vanda na criação de um território vinculante e reparador para o seu cotidiano, a tática de meter o louco aconteceu, nos dois casos mencionados, em situações limite onde o corpo era o único território possível para ação. Quando não existem meios ou plataformas mínimas para (re) agir diante das adversidades, o corpo se torna instrumento primordial de resistência, território último onde é possível fazer a vida perseverar.

Meter o louco pra rodar o sistema se aproxima das táticas mobilizadas durante o Dirty Protest na medida em que lança mão de soluções que borram as fronteiras entre a promoção da vida e a condução da morte. Se opor diametralmente às formas de violência e destituição operadas pela máquina do Estado implica trafegar em regiões liminares, onde o corpo pode se tornar o único abrigo, ainda que frágil e desgastado, para reverter os vetores de força e produzir uma forma de existência considerada digna, mesmo que, com isso, coloque fim a própria vida.

Pela boqueta da cela do castigo da Penitenciária Feminina de Santana, Pereira dizia que o tempo de vida passado entre grades não foi tempo em branco, porque lá, a despeito de todas as adversidades, ele conseguiu criar meios de habitar, de amar, de se territorializar. Ser transferido da penitenciária em que viveu os último oito anos, na reta final do cumprimento de sua pena, significaria fazer desse tempo restante aquilo que ele consideraria um tempo em branco: dias de vida suportados enquanto aguardava a chegada de um outro lugar. Meter o louco durante meses a fio, destruindo, quebrando, se cortando, dormindo e marchando, numa linha de fuga feita máquina de guerra se tornou, em última análise, uma de forma de se mantervivo, dentro daquilo que considera ser uma vida possível, uma vida vivível.

Sara Vieira Antunes é mestra em Antropologia Social pela Universidade Estadual de Campinas (UNICAMP) e doutoranda no Programa de Pós-Graduação em Antropologia Social pela Universidade de São Paulo, USP (bolsista Fapesp). Integra o Núcleo de Antropologia do Direito (Nadir-USP) e, atualmente, pesquisa os seguintes temas: prisão, loucura, medida de segurança, sistema de justiça e tecnologias de poder.

CONTRIBUIÇÃO DE AUTORIA: Não se aplica

FINANCIAMENTO: Fundação de Amparo à Pesquisa do Estado de São Paulo (FAPESP). 


\section{REFERENCIAS BIBLIOCRÁFICAS}

ADORNO, Sérgio. e SALLA Fernando. 2007. "Criminalidade organizada nas prisões e o ataque do PCC". Estudos avançados. v.21, n.61: 7-29. https://doi. org/10.1590/S0103-40142007000300002

BARBOSA, Antônio Rafael. 2013. "Grade de ferro? Corrente de ouro!": circulação e reações no meio prisional. Tempo Social. v. 25, n. 1: 107-129. https://doi. org/10.1590/S0103-20702013000100006

BARBOSA, Antônio Rafael. 2005. Prender e Dar Fuga: Biopolítica, Sistema Penitenciário e Tráfico de Drogas no Rio de Janeiro. Rio de Janeiro, tese de doutorado, Museu Nacional - Universidade Federal do Rio de Janeiro.

BIONDI, Karina. 2009. Junto e Misturado: Imanência e Transcendência no PCC. São Carlos, dissertação de mestrado, Universidade Federal de São Carlos.

DAS, Veena. 2007. Life and Words: violence and the descent into the ordinary. Berkeley and Los Angeles, California: University of California Press.

DE CERTEAU, Michel. [1990] 2014. A invenção do cotidiano: as artes de fazer. Petrópolis, Vozes.

CUNHA, Manuela Ivone da. 2003. O bairro e a prisão: a erosão de uma fronteira. Braga, Universidade do Minho, CCHS, IDEMEC.

DIAS, Camila Caldeira Nunes. 2011. Da pulverização ao monopólio da violência: expansão e consolidação do Primeiro Comando da Capital (PCC) no sistema carcerário paulista. São Paulo, tese de doutorado, Universidade Estadual de São Paulo..
DELEUZE, Gilles e GUATTARI, Felix. [1980] 1997. Mil platôs: capitalismo e esquizofrenia. 5v. São Paulo, Ed. 34.

FELDMAN, Allen. 1991. Formations of violence: The narrative of the Body and Political Terror in Northern Ireland. Chicago: The University of Chicago Press..

FELTRAN, Gabriel. 2008. Fronteira de tensão: um estudo sobre política e violência nas periferias de São Paulo. Campinas, tese de doutorado, Unicamp/IFCH.

GODOI, Rafael. 2010. Ao redor e através da prisão: cartografias do dispositivo carcerário contemporâneo. São Paulo, dissertação de mestrado, Universidade de São Paulo.

GODOI, Rafael. 2015. Fluxos em cadeia: as prisões em São Paulo na virada dos tempos. São Paulo, tese de doutorado, Faculdade de Filosofia Letras e Ciências Humanas, Universidade de São Paulo.

GOFFMAN, Erving. [1961] 2001.

Manicômios, Prisões e Conventos. São

Paulo: Editora Perspectiva.

KASPER, Christian Pierre. 2006. Habitar a rua. Campinas, tese de doutorado, Universidade Estadual de Campinas.

LIMA, Jaqueline Ferraz. 2013. Mulher Fiel: as famílias das mulheres dos presos relacionados ao Primeiro Comando da Capital. São Carlos, dissertação de mestrado, Universidade Federal de São Carlos.

MALLART, Fábio M. 2011. Cadeias Dominadas: Dinâmicas de uma instituição em trajetórias de jovens internos. São Paulo, dissertação de mestrado, Universidade de São Paulo. 
ARTICo | Sara Vieira Antunes | "Eu tô vivo e isso aqui é minha vida agora": produção de territórios e condições de existência no cotidiano de uma prisão

MALLART, Fábio. 2019. Findas linhas: circulações e confinamentos pelos subterrâneos de São Paulo. São Paulo, tese de doutorado, Universidade de São Paulo.

MALVASI, Paulo Artur. 2012. Interfaces da vida loka: um estudo sobre jovens, tráfico de drogas e violência em São Paulo. São Paulo, tese de doutorado, Universidade de São Paulo.

MARQUES, Adalton. 2009. Crime, proceder, convívio-seguro: Um experimento antropológico a partir de relações entre ladrões. São Paulo, dissertação de mestrado, Universidade de São Paulo, São Paulo.

PADOVANI, Natália C. 2015. Sobre casos e casamentos: afetos e amores através de penitenciárias femininas em São Paulo e
Barcelona. Campinas, tese de doutorado, Universidade Estadual de Campinas.

PERLONGHER, Nestor. [1987] 2008. O negócio do michê. São Paulo, Editora Fundação Perseu Abramo.

STRATHERN, Marylin. 2014. "O efeito etnográfico". In: STRATHERN, Marylin. O efeito etnográfico e outros ensaios. São Paulo, Cosac Naify pp. 345-406.

TELLES, Vera e HIRATA, Daniel. 2007. “Cidade e práticas urbanas: nas fronteiras incertas entre o ilegal, o informal e o ilícito". Revista Estudos Avançados, n. 21 (61): 173-191. https:// doi.org/10.1590/S0103-40142007000300012

ZOUTABICHVILI, François. 2004. Vocabulário de Deleuze. Rio de Janeiro, R]: Relume Dumará.

Recebido em 18 de fevereiro de 2019. Aceito em 25 de agosto de 2020. 